\title{
Rhythmic episodes of heating and cooling control thermal stratification of two tropical high mountain lakes
}

\author{
Javier Alcocer ${ }^{1}$. Jennifer Roberson ${ }^{2} \cdot$ Luis A. Oseguera $^{1} \cdot$ William M. Lewis Jr. ${ }^{2,3}$ (1)
}

Received: 10 June 2019 / Accepted: 16 May 2020 / Published online: 23 May 2020

(c) The Author(s) 2020

\begin{abstract}
Continuous temperature monitoring for two adjacent tropical crater lakes in Mexico at $4200 \mathrm{~m}$ amsl shows that the lakes have rhythmic episodes of heating and cooling with a duration of $\sim 30$ days during the warmest months. The episodes were caused by rise and decline of solar irradiance reaching the lake surface. One lake, El Sol, showed over each heating and cooling episode a stable mixed layer ( 20 days) and a deeper layer with a weak thermal gradient. Temperatures below the mixed layer warmed progressively by eddy diffusion after the mixed layer formed. Stratification was followed by full mixing of the water column. Within the same crater, an adjacent second lake, La Luna, showed the same cycles of heating and cooling; it stratified daily but not over multiple days. The difference between the lakes (discontinuous polymictic, continuous polymictic) is explained by the lower transparency of El Sol, which led to greater heat uptake near the surface than the more transparent La Luna. Lower transparency of El Sol was caused by modest anthropogenic effects on total suspended solids and nutrient loading, i.e., small deviations from the natural condition of El Sol caused it to differ qualitatively from La Luna. Events observed in these lakes would not have been evident from weekly temperature records.
\end{abstract}

Keywords Lake polymixis · Thermal stratification · Lake heat budgets

\section{Introduction}

Lakes at high elevation in the tropics were first studied extensively by Löffler $(1964,1972)$, who designated lakes above $3000 \mathrm{~m}$ amsl as "high mountain tropical," which

William M. Lewis Jr.

lewis@colorado.edu

Javier Alcocer

jalcocer@unam.mx

Jennifer Roberson

jennifer.roberson@colorado.edu

Luis A. Oseguera

loseguera@unam.mx

1 Grupo de Investigación en Limnología Tropical, Facultad de Estudios Profesionales Iztacala, Universidad Nacional Autónoma de México, Av. de los Barrios No. 1, Los Reyes Iztacala, 54090 Tlalnepantla, Mexico, Mexico

2 Center for Limnology, Cooperative Institute for Research in Environmental Sciences, 216 UCB, University of Colorado, Boulder, CO 80309-0216, USA

3 Department of Ecology and Evolutionary Biology, 334 UCB, University of Colorado, Boulder, CO 80309-0216, USA in the American tropics are typically referred to as either "paramo" (wet, narrow temperature range) or "puna" (dry, broad temperature range). Löffler observed that tropical high mountain lakes typically lack a seasonal, stable ice cover, but may develop full or partial ice cover for brief intervals. Hutchison and Löffler (1956) also concluded that many tropical high mountain lakes are polymictic but, if deep, can be warm monomictic, i.e., show complete mixing of the water column on a seasonal basis alternating with seasonal stratification of the water column, as does Lake Titicaca (Andes, 3800 m amsl: Vincent et al. 1984; Richerson et al. 1986). Small mountain lakes, however, have proven to be mainly continuous or discontinuous polymictic (e.g., Eggermont et al. 2007), although climatic warming could move polymictic lakes toward warm monomixis (Michuletti et al. 2016; Woolway and Merchant 2019). Montane lakes below the high mountain zone are more likely to be warm monomictic than higher lakes (Gunkel and Casellas 2002; Salas De Leon et al. 2016).

The present study uses continuous water column temperature measurements as a basis for analysis of heat flux and vertical heat distribution in two tropical high mountain crater lakes, El Sol and La Luna, that are located in the Mexican 
Volcanic Belt (Fig. 1). A previous study (Tarabay et al. 1991) has shown that the lakes do not stratify for an entire season, have maximum surface temperatures near $13^{\circ} \mathrm{C}$, and develop ice cover briefly in some years. The high frequency temperature record for both lakes at multiple depths allows quantification of daily temperatures and heat flux revealing a previously undocumented rhythmic pattern of heat uptake and loss that may be found in other lakes. El Sol and La Luna are among the highest of lakes that have been studied and demonstrate, through interpretation of the continuous record, exceptional sensitivity in heat flux and heat distribution, especially in response to relatively small watershed effects on transparency. The purpose of analysis for temperature distribution and water column stability for the two high mountain tropical lakes is to determine the degree to which such lakes can be stratified under conditions that minimize seasonal trends in heat flux.

\section{Study site}

The volcano Nevado de Toluca, also known as Xinantécatl $\left(19^{\circ} 06^{\prime} 30^{\prime \prime} \mathrm{N}\right.$; 99 $99^{\circ} 45^{\prime} 30^{\prime \prime} \mathrm{W}$; $4230 \mathrm{~m}$ amsl), is located $\sim 80 \mathrm{~km}$ WSW of Mexico City (Fig. 1). Rising to 4,680 m amsl, this broad stratovolcano forms the fourth highest mountain in Mexico. Its last eruption occurred 2300 years BP (Arce et al. 2005). It has a complex, elongated crater of 2-2.5 km width. Within this crater, a lava dome separates two lakes, El Sol and La Luna. Morphometric features of the lakes (Alcocer 1980) include: maximum length $795 \mathrm{~m}$ (El Sol), 227 m (La Luna); maximum width 482 m (El Sol), 209 m
(La Luna); shoreline length $2363 \mathrm{~m}$ (El Sol), $675 \mathrm{~m}$ (La Luna); mean depth $6 \mathrm{~m}$ (El Sol), $5 \mathrm{~m}$ (La Luna); relative depth $2.77 \%$ (El Sol), $5.05 \%$ (La Luna); shoreline development 1.4 (El Sol), 1.1 (La Luna). El Sol has a watershed of $240 \mathrm{ha}$; La Luna's watershed is 74 ha. For both watersheds, vegetation is sparse and consists of mosses, lichens, and alpine grasses. Soils are thin and coarse (gravel, sand) but may be more compact on irregularities in crater walls. Both lakes are visited by tourists who may park within the watershed and walk near the lakes. El Sol has a much higher human presence because it is more accessible than La Luna. There are no toilet facilities at either site. Open range cattle have access to the lakes, where they seek water; vegetation is too sparse to support intensive grazing near the lakes. Cattle at lakeside are more abundant for El Sol than La Luna. The regional lands outside the crater are warmer than the lake watersheds (mean temperature $17.7^{\circ} \mathrm{C}$ ) but show the seasonal rainfall of the lakes $\left(900 \mathrm{~mm}\right.$ year $^{-1}$, hemispheric summer).

During a 1-year study of the two lakes (2007), monthly mean air temperatures ranged between $2.4^{\circ} \mathrm{C}$ in February and $5.2{ }^{\circ} \mathrm{C}$ in April; annual mean was $3.9^{\circ} \mathrm{C}$. Annual precipitation was $1243 \mathrm{~mm}$ (range $17 \mathrm{~mm}$ in December, $270 \mathrm{~mm}$ in July). The narrow air temperature range and moisture are typical of high mountain paramo (Löffler 1964), although Tarabay et al. (1991) classified the climate of the lakes as intermediate between paramo and puna.

At capacity, maximum depth of El Sol is $15 \mathrm{~m}$, but in 2007 it was $12 \mathrm{~m}$ and surface area was $19 \mathrm{ha}$; maximum depth of La Luna was $10 \mathrm{~m}$, which was also the maximum depth during the 2007 study; surface area was 3 ha.
Fig. 1 Location map and contour maps for Nevado de Toluca and the two lakes (grey lines show 20-m intervals, black lines show $100-\mathrm{m}$ intervals, blue lines show intervals of $3 \mathrm{~m}$ )

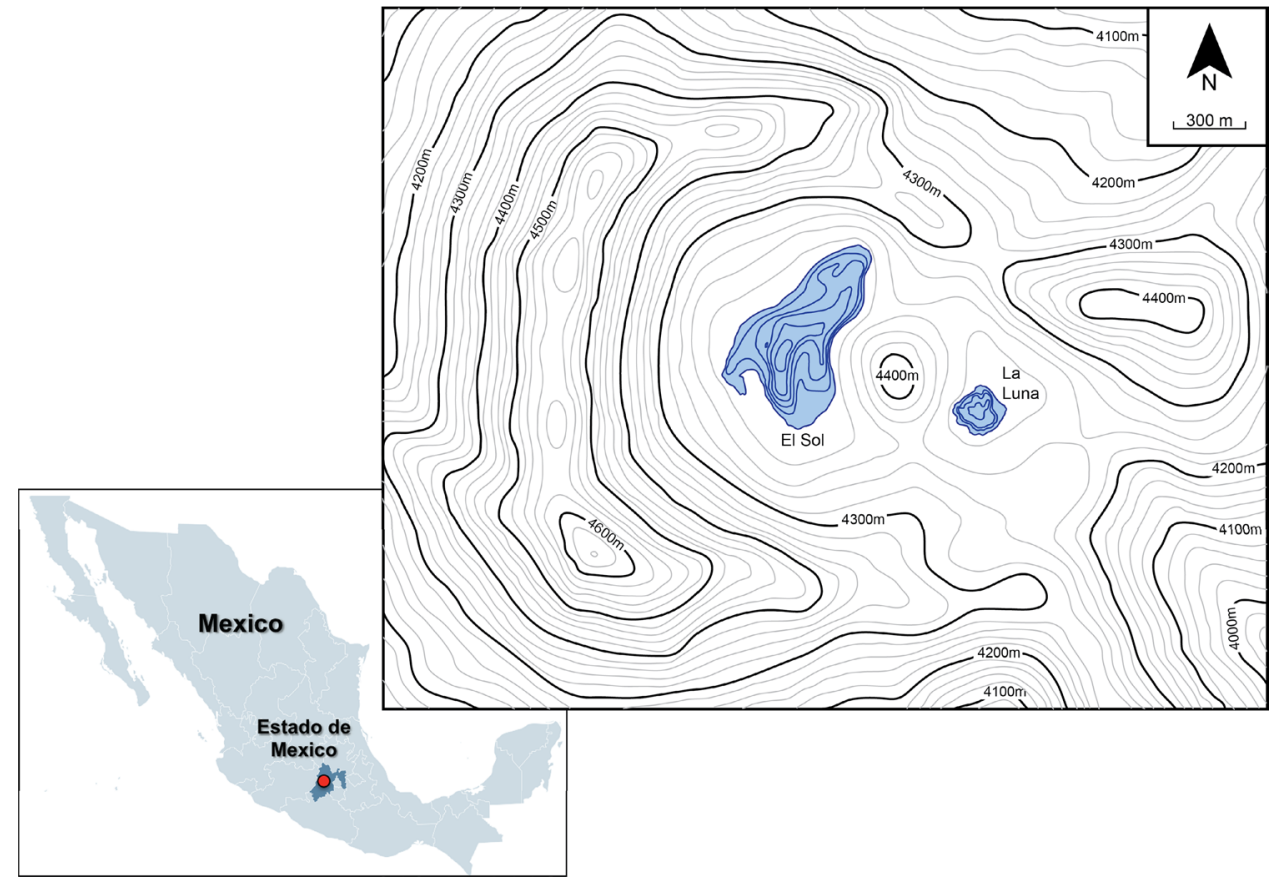


Crater lakes often are shielded from wind stress by crater walls. The minimum height of the crater wall above the two lakes is $\sim 400 \mathrm{~m}$. The ratio of maximum distance across a volcanic lake $(\mathrm{L})$ to minimum crater wall height $(\mathrm{H})$ is an index of the relative suppression of wind velocity across crater lakes (Melack and MacIntyre 2016). For the two lakes, the ratios are 0.9 (El Sol) and 0.6 (La Luna). A review of comparable ratios for tropical lakes at lower elevations shows $\mathrm{L} / \mathrm{H}$ values are often $0.5-1.0$ (Melack and MacIntyre 2016); El Sol and La Luna have wind shielding that is typical for tropical crater lakes.

\section{Methods}

Temperature of the two lakes was measured at 15-min intervals from surface to bottom over deepest water with U22001 HOBO Pro v2 loggers (accuracy $\pm 0.21^{\circ} \mathrm{C}$, resolution $0.02{ }^{\circ} \mathrm{C}$, stability $0.1{ }^{\circ} \mathrm{C}$ year ${ }^{-1}$ ), at 5 depths from January 1st to 31 December 2007. Prior to placement in the lakes, loggers were stored in a container for $24 \mathrm{~h}$ to record data for mutual calibration. The differences between average temperatures of each logger and average of all loggers during the period were used to standardize temperatures among loggers.

Heat budget calculations were made by the Birgean method (Kalff 2002); stability calculations followed Eq. 7 from Idso (1973). Meteorological data (solar irradiance, air temperature) were obtained for the year from the Nevado de Toluca Automatic Meteorological Station (EMA) of the

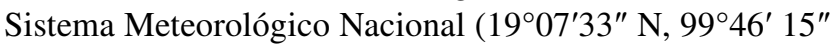
$\mathrm{W}, 4139 \mathrm{~m} \mathrm{amsl}), 1.4 \mathrm{~km} \mathrm{NE}$ of the crater.

Water quality data were collected monthly for each of the lakes. Secchi depth was measured and profiles of photosynthetically active radiation (PAR) were collected with a quantum sensor. Monthly profiles were obtained for specific conductance (corrected to $25^{\circ} \mathrm{C}$ ), total suspended solids as dry mass were collected on Whatman GF/F filters, and chlorophyll a was analyzed by USEPA method 445.0 (acetone extraction plus fluorometry). Estimates of eddy diffusion coefficients were made by the method of Jassby and Powell (1975), which is based on the change in thermal gradient over time at a specific depth within the stably stratified zone of a lake. The estimates were made only for El Sol because La Luna was not stably stratified.

\section{Results}

As shown in Fig. 2, monthly average solar irradiance for El Sol showed a strong negative correlation to relative humidity $\left(\mathrm{r}^{2}=38 \%, \mathrm{p}<0.0001\right)$. This relationship was associated with a seasonal pattern in irradiance that shows irradiance between 400 and $500 \mathrm{~W} \mathrm{~m}^{-2}$ between November and April and $300-400 \mathrm{~W} \mathrm{~m}^{-2}$ between May and November. Wind strength was notably higher in January and February (average $5.7 \pm 3.1 \mathrm{~m} \mathrm{~s}^{-1}$ ) than in other months; it ranged between 3.3 and $5.0 \mathrm{~m} \mathrm{~s}^{-1}$ in other months, and lacked a significant trend.

\section{Factors potentially affecting heat distribution and mixing}

The two lakes had conductance differentiation over depth of less than $3 \mu \mathrm{S} \mathrm{cm}^{-1}$, indicating no significant effects of salinity on vertical mixing. Specific conductance ranged seasonally between 45 and $65 \mu \mathrm{S} \mathrm{cm}^{-1}$ for El Sol and 3-10 $\mu \mathrm{S} \mathrm{cm}^{-1}$ for La Luna.

Suspended solids or chromatic dissolved solids can significantly magnify the rate of absorbance for downwelling solar irradiance, thereby causing strong diurnal heating of the top few meters of a lake (Read and Rose 2013; Rose et al. 2016; Melack and MacIntyre 2016). El Sol had moderate concentrations of suspended solids (monthly means, $1.0-2.5 \mathrm{mg} \mathrm{L}^{-1}$ ), and La Luna had low concentrations (0.3-1.4 $\left.\mathrm{mg} \mathrm{L}^{-1}\right)$. El Sol had high concentrations of dissolved organic carbon (DOC: 7.6, 8.0 $\mathrm{mg} \mathrm{L}^{-1} \mathrm{Jan} 10$, Feb 21, 2017); La Luna had much lower amounts $\left(1.8,1.9 \mathrm{mg} \mathrm{L}^{-1}\right.$, same dates). Monthly chlorophyll at $1 \mathrm{~m}$ was $0.7-2.5 \mu \mathrm{g} \mathrm{L}^{-1}$ (mean $1.5 \mu \mathrm{g} \mathrm{L}^{-1}$ ) for El Sol and 0.2-0.7 $\mu \mathrm{g} \mathrm{L}^{-1}$ (mean $0.4 \mu \mathrm{g} \mathrm{L}^{-1}$ ) for La Luna. Concentrations of chlorophyll were only slightly lower at greater depths for both lakes.

\section{Temperature, layering, and mixing}

Water temperature rose steadily from January through June, then decreased steadily for the next 6 months. Air temperature showed a similar trend, but with warming extended to August rather than June. The combined effects of weather on heat budgets, as shown by monthly averages for heat flux (Fig. 2d) produced weak trends in heat exchange.

Both lakes showed strong seasonal trends in temperature (Fig. 3); they were coolest in the hemispheric winter months (December, January), then warmed to a maximum at the end of August. Episodic surges in temperature followed by an interval of maximum temperature and then a compensatory decline occurred synchronously in the two lakes. One episode occurred during the coolest month (January) and six occurred during warming and peak heat content. After August, when cooling began, similar surges occurred but were of lower amplitude; they were partly obscured by rapid cooling (Fig. 3). The nonseasonal warming and cooling episodes were rhythmic; they were separated by a brief interval of low surface temperature (Fig. 3). For El Sol, the warm season episodes had a mean duration of 26 days (range 21-35 days) 

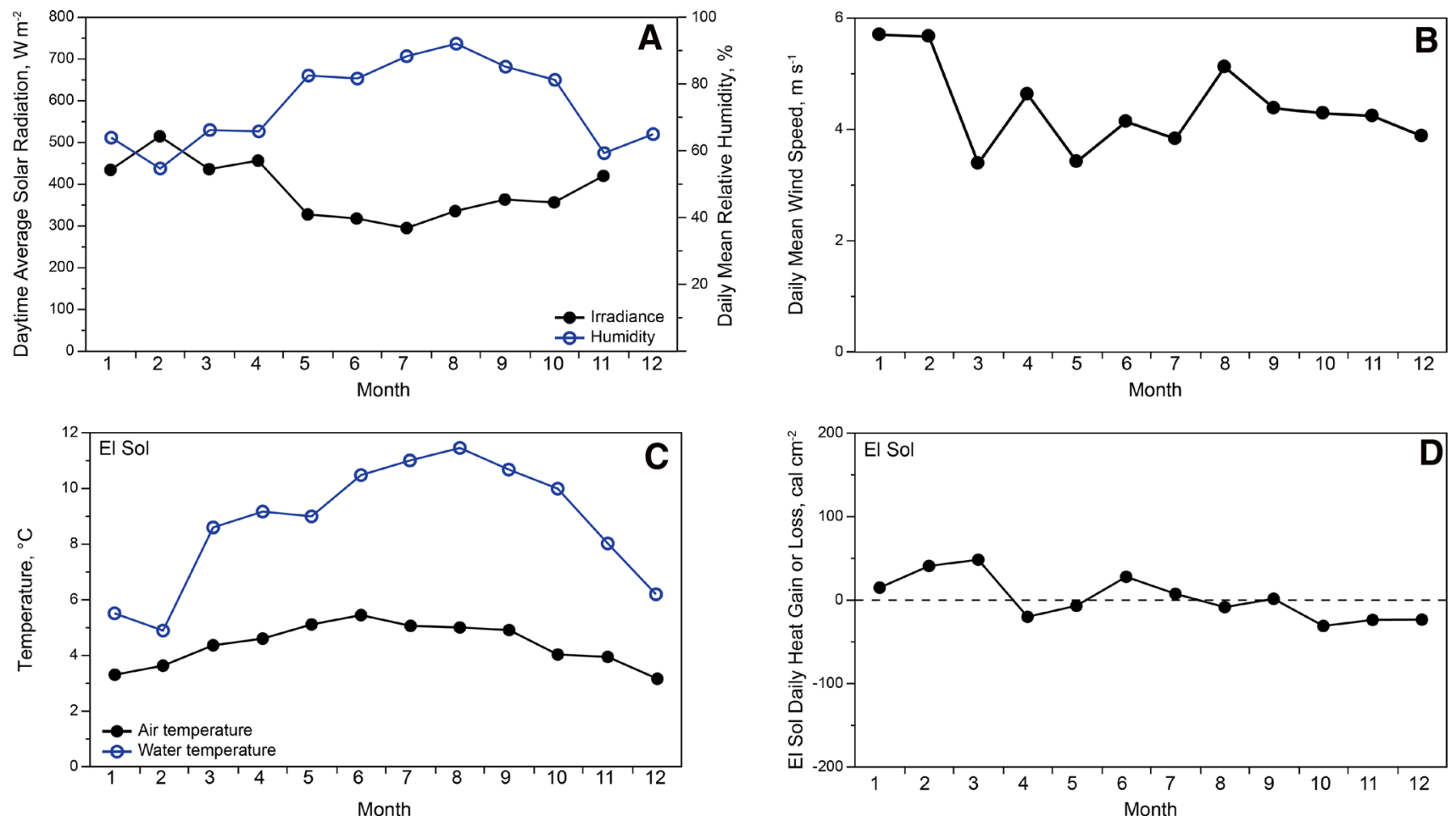

Fig. 2 Monthly data for the weather station and El Sol: irradiance and humidity (a), wind speed (b), air and water temperature (c), daily heat flux (d)

and mean amplitude of $2.4{ }^{\circ} \mathrm{C}$ (range $1.0-3.5^{\circ} \mathrm{C}$ ). For La Luna, the pattern was nearly identical. Warming surges in the two lakes corresponded to intervals of $\sim 5$ days during which two or more days had mean daytime total irradiance $>250 \mathrm{~W} \mathrm{~m}^{-2}$. Subsequent cooling coincided with a decline in solar irradiance involving one or more days $<100 \mathrm{~W} \mathrm{~m}^{-2}$. Autocorrelation analysis for solar irradiance during the warm season (1 March-August 30) shows strong positive correlation for a 1 -day lag $(\mathrm{r}=0.57)$, and declining positive correlations for progressively longer lags up to $\sim 12$ days, after which correlations are near zero. Beyond 21 days, positive correlations reappear and reach a peak centered on 24 days $(r=0.25)$, after which they recede.

Air temperatures seldom exceeded $6{ }^{\circ} \mathrm{C}$ and typically were much lower than water temperatures (Fig. 2). Air temperatures responded to solar irradiance, as did lake temperatures. The highest wind velocities (Fig. 2) occurred when the lakes were coolest (January-February, $5.8 \mathrm{~m} \mathrm{~s}^{-1}$ for both months). Median wind velocity for means across all months was $4.2 \mathrm{~m} \mathrm{~s}^{-1}$. Solar irradiance was not correlated with wind velocity $(\mathrm{p}>0.05)$.

The annual maximum surface to bottom temperature difference in El Sol during the warm season was $0.72{ }^{\circ} \mathrm{C}$; for La Luna it was $0.28{ }^{\circ} \mathrm{C}$. Surface-bottom temperature differences in El Sol showed more variation than in $\mathrm{La}$ Luna during the warm season.

El Sol was stratified for most of each episode of warming and cooling. Its mixed layer consistently extended to 5-7 m. Stability in layering began on the first day of each thermal surge and persisted through part of the cooling phase, after which mixing occurred briefly until the next surge began (Fig. 4). Time intervals for full water column mixing were determined from temperature profiles of the lakes at a time of daily minimum heat content (Fig. 4).

Surface warming of El Sol was accompanied by warming at all depths below the mixed layer during each surge and extended into the cooling phase, even though the water column was stably stratified (Fig. 5). Vertical eddy diffusion coefficients $\left(\mathrm{K}_{\mathrm{z}}\right)$ were estimated for $6 \mathrm{~m}$, near the bottom of the mixed layer, and at $9 \mathrm{~m}, 3 \mathrm{~m}$ above the lake bottom, for the interval July 5-15, during a warming phase. The values of $\mathrm{K}_{\mathrm{z}}$ were identical for the two depths: $0.012 \mathrm{~cm}^{2} \mathrm{~s}^{-1}$.

La Luna showed weak, shallow $(3 \mathrm{~m})$ stratification during thermal surges, but the record for temperatures (Fig. 4) shows that the lake always was isothermal by early morning. La Luna had lower diel variation in temperature near the surface than El Sol and greater warming at depth (Fig. 5). 
Fig. 3 Plots of water temperature (daily averages) and total surface irradiance (grey, daily mean for daylight hours) for 2007 in lakes El Sol and La Luna. Temperatures for five depths are shown for each lake
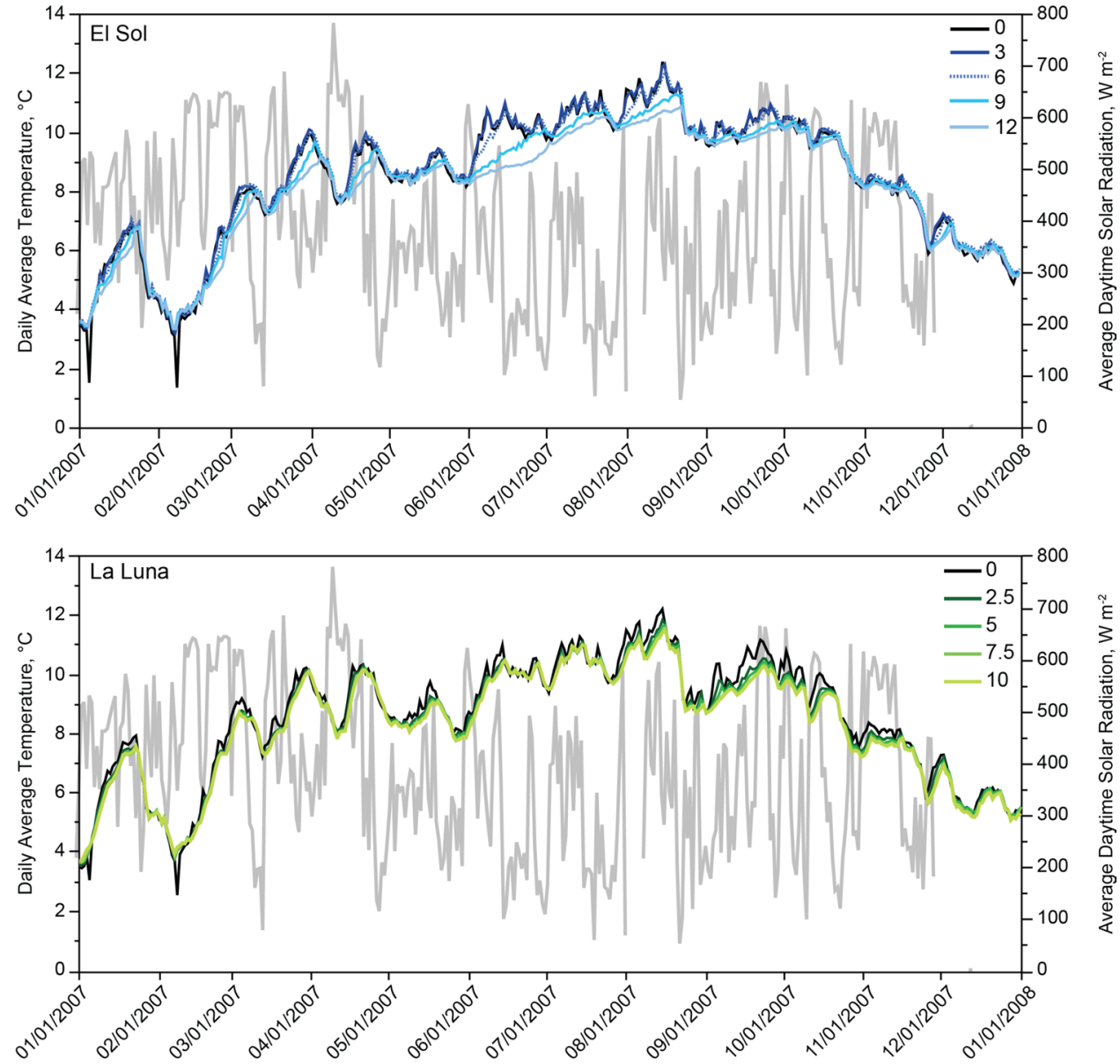

Heat flux, budgets, and water column stability

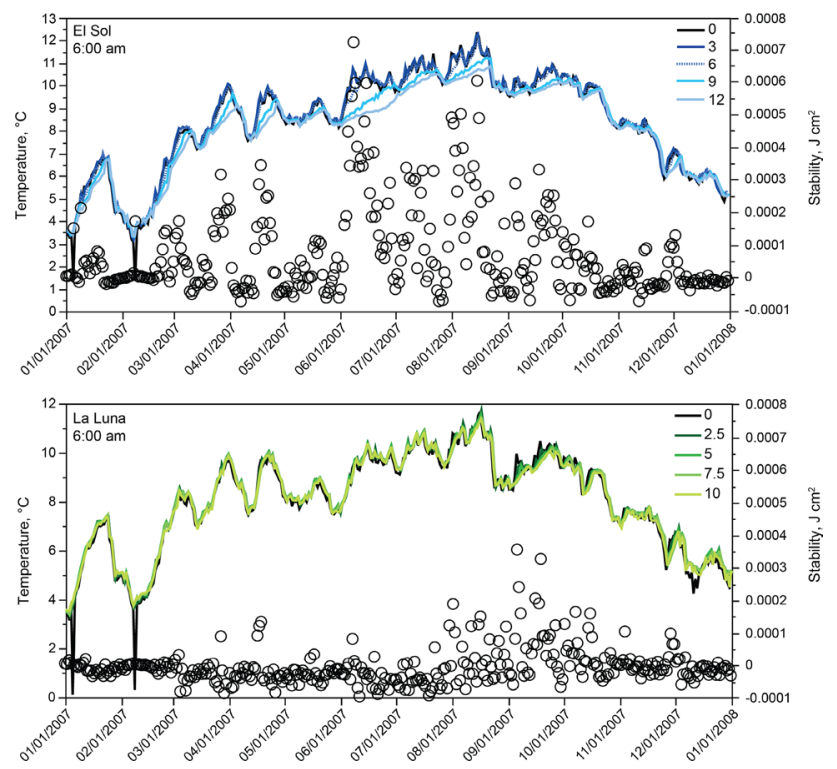

Fig. 4 Annual temperature profiles at a time of minimum daily heat content and Schmidt water column stability for the two lakes
Heat exchange was steadily positive from January to February, then unstable for the next four months and, beginning in August, showed a steady decline. Daily heat flux for the two lakes showed very little seasonality (Fig. 6), despite the pronounced seasonality of surface temperatures (Fig. 2). The 95th percentile 5-day gain was nearly the same for El Sol $\left(200 \mathrm{cal} \mathrm{cm}^{-2} \mathrm{day}^{-1}\right)$ and La Luna $\left(215 \mathrm{cal} \mathrm{cm}^{-2} \mathrm{day}^{-1}\right)$; the 95 th percentile 5-day heat loss was $-240 \mathrm{cal} \mathrm{cm}^{-2} \mathrm{day}^{-1}$ for El Sol and $-275 \mathrm{cal} \mathrm{cm}^{-2} \mathrm{day}^{-1}$ for La Luna. Extreme single day values (Fig. 6) may appear to be erroneous, but their synchrony for the two lakes suggests that they are valid.

Birgean annual heat budgets for the two lakes were similar (Table 1), even though El Sol had a much higher maximum annual stability than La Luna (Table 1). Both lakes showed large changes in stability within months (Fig. 4), but the variance in stability within and across months was much higher for El Sol than for La Luna. Stability showed some seasonality, which was much greater for El Sol than for La Luna. Stability was highest for El Sol at peak temperatures corresponding to temperature surges from May 

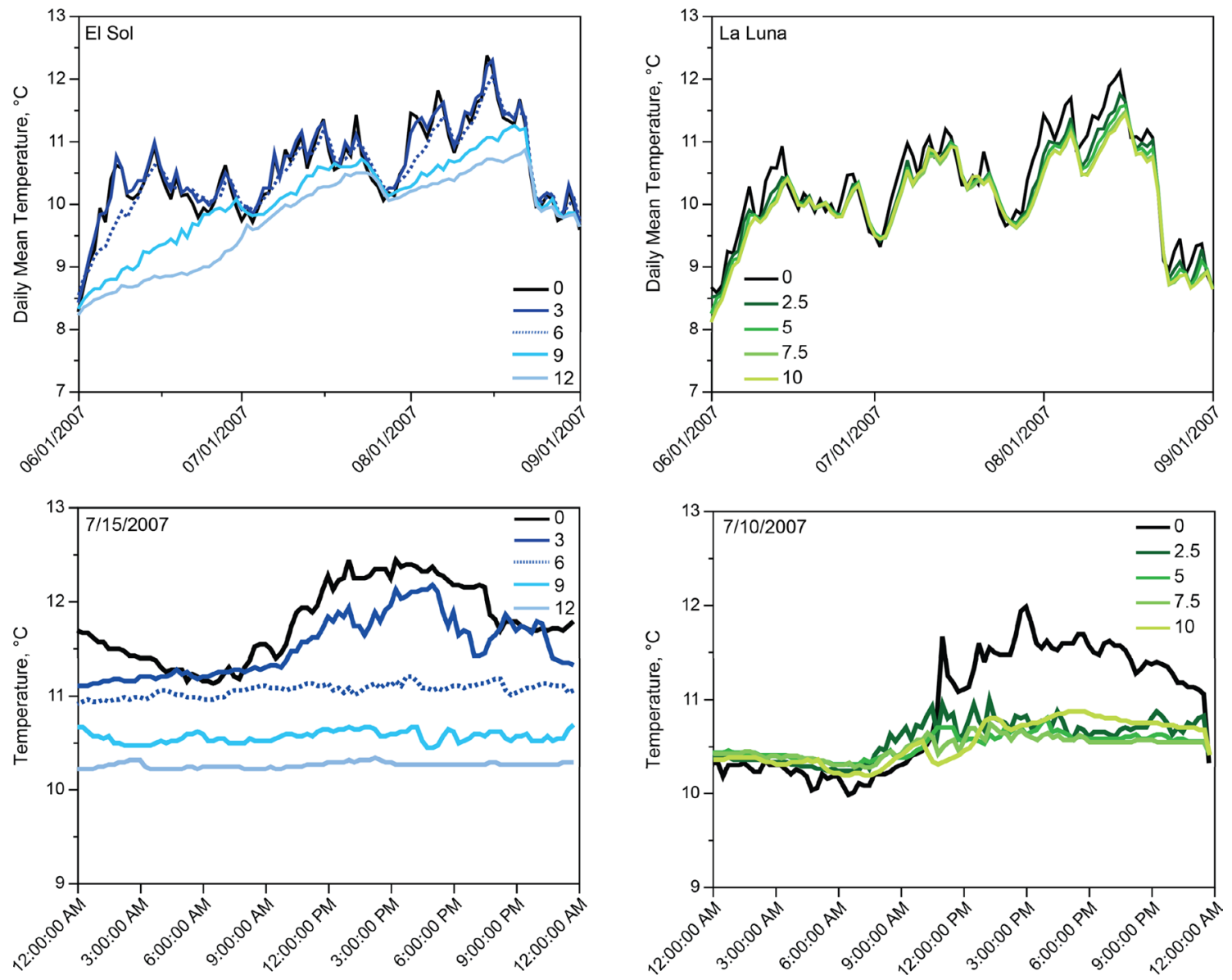

Fig. 5 Top: enlarged graph of three warming episodes showing the degree of warming at depth for the two lakes. Bottom: diel changes in thermal stratification during a warming surge
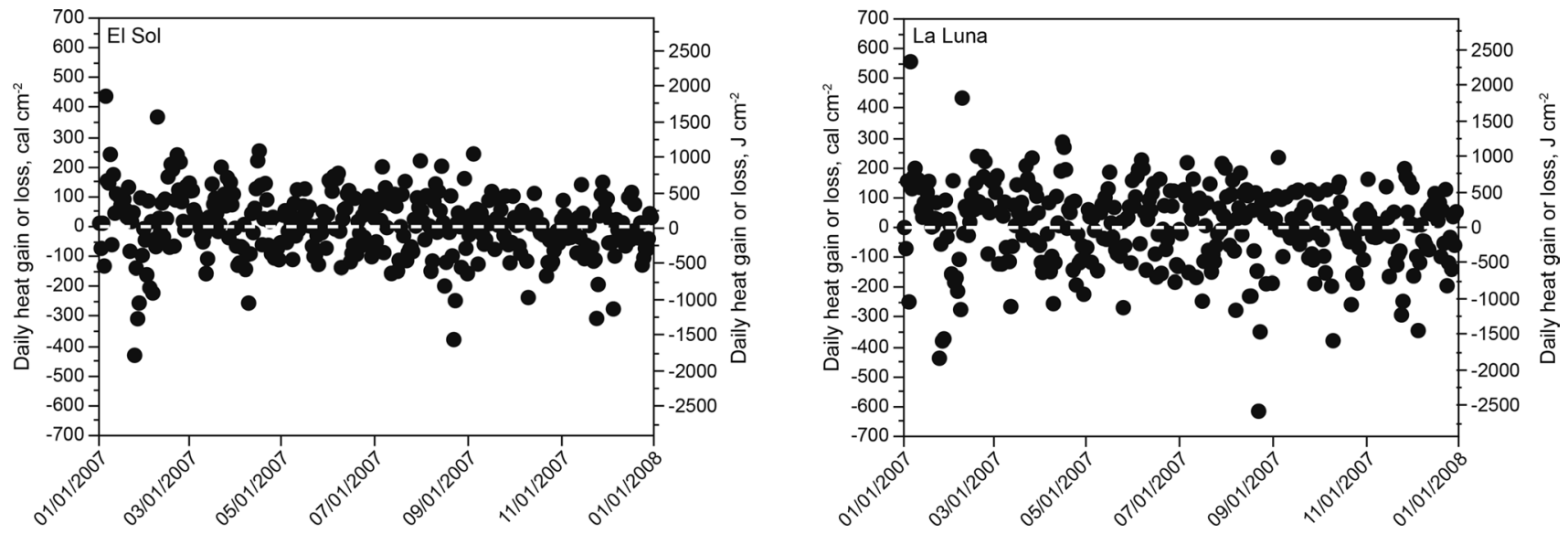

Fig. 6 Daily heat gain and loss for El Sol and La Luna

through September. Stability was highest for La Luna from August through October.

El Sol had much higher PAR absorbance than La Luna (Fig. 7). Estimates can be made of relative contributions to PAR light absorption by water, DOC, chlorophyll a, and suspended solids other than phytoplankton. For water, the extinction coefficient $\left(\mathrm{K}_{\mathrm{w}}\right)$ depends on depth (Kirk 1974). For the middle water column of the two lakes, $\sim 6 \mathrm{~m}$, the 
Table 1 Summary statistics of temperature, heat, and stability for El Sol and La Luna

\begin{tabular}{|c|c|c|}
\hline & El Sol & La Luna \\
\hline Maximum temperature, ${ }^{\circ} \mathrm{C}$ & 12.4 & 11.7 \\
\hline Mean temperature, ${ }^{\circ} \mathrm{C}$ & 8.3 & 8.1 \\
\hline Minimum temperature, ${ }^{\circ} \mathrm{C}$ & 1.3 & 0.1 \\
\hline Maximum heat gain, cal cm${ }^{-2}, 5$ day, day $^{-1}\left(\mathrm{~J} \mathrm{~cm}^{-2}\right)$ & $181(758)$ & 239 (1001) \\
\hline Maximum heat loss, cal $\mathrm{cm}^{-2}, 5$ day, day ${ }^{-1}\left(\mathrm{~J} \mathrm{~cm}^{-2}\right)$ & $-220(921)$ & $-247(1034)$ \\
\hline Annual heat budget, cal $\mathrm{cm}^{-2}\left(\mathrm{~J} \mathrm{~cm}^{-2}\right)$ & $4354(18,229)$ & $4241(17,756)$ \\
\hline 95 percentile daily heat gain, $\mathrm{cal} \mathrm{cm}^{-2}\left(\mathrm{~J} \mathrm{~cm}^{-2}\right)$ & $200(837)$ & $215(900)$ \\
\hline 95 percentile daily heat loss, cal $\mathrm{cm}^{-2}\left(\mathrm{~J} \mathrm{~cm}^{-2}\right)$ & $-240(1005)$ & $-245(1026)$ \\
\hline Maximum stability, $\mathrm{g} \mathrm{cm} \mathrm{cm}^{-2}\left(\mathrm{~J} \mathrm{~cm}^{-2}\right)$ & $7.4(0.0007)$ & $3.6(0.0004)$ \\
\hline Minimum stability, $\mathrm{g} \mathrm{cm} \mathrm{cm}^{-2}\left(\mathrm{~J} \mathrm{~cm}^{-2}\right)$ & $-0.7(-0.0001)$ & $-1.1(-0.0001)$ \\
\hline
\end{tabular}
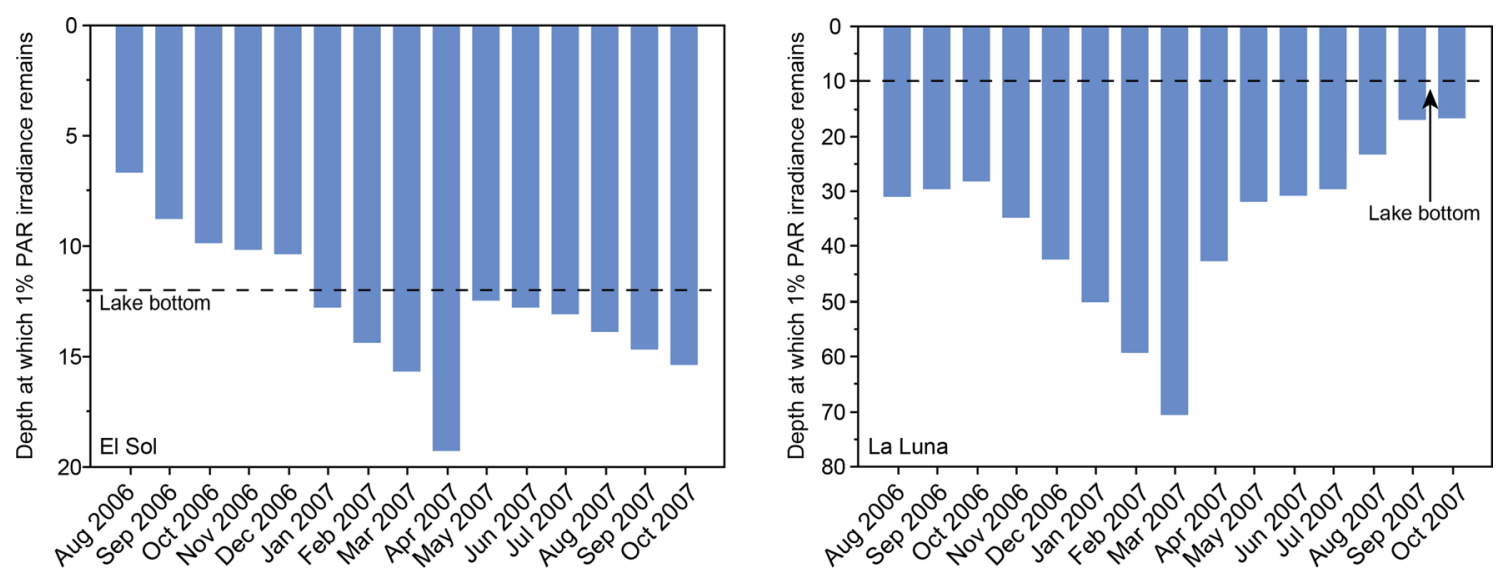

Fig. 7 Monthly depth of $1 \%$ surface irradiance in the two lakes. Dashed line is the lake depth at the time of the study. Note the compressed scale for La Luna

value of $\mathrm{K}_{\mathrm{w}}$ was $\sim 0.1 \mathrm{~m}^{-1}$ (Lewis 2011). In the absence of humic and fulvic acids, DOC absorption of PAR $\left(\mathrm{K}_{\mathrm{g}}\right.$, gilvin) would have been trivial and is set to $0.1 \mathrm{~m}^{-1}$.

Chlorophyll and suspended solids varied in concentration on a seasonal basis, which significantly affected extinction coefficients. The effect of chlorophyll on PAR extinction can be estimated as $0.014 \mathrm{~m}^{-1}$ per $\mu \mathrm{g} \mathrm{L}{ }^{-1}$ (Reynolds 2006). The warm months for El Sol had the highest concentrations of chlorophyll $\left(4.8 \mu \mathrm{g} \mathrm{L}^{-1}, \mathrm{~K}_{\mathrm{a}}=0.07 \mathrm{~m}^{-1}\right)$. For La Luna, the highest chlorophyll a was $0.4 \mu \mathrm{g} \mathrm{L}^{-1}$ (December, $\mathrm{K}_{\mathrm{a}} \leq 0.01 \mathrm{~m}^{-1}$ ).

Extinction coefficients differ for detrital and inorganic solids. There is no empirical basis for estimating relative amounts of these two components in the lakes, but organic solids are scarce in the watersheds of El Sol and La Luna. Inorganic solids are assumed dominant, corresponding to $\mathrm{K}_{\mathrm{p}} \approx 0.16 \mathrm{~m}^{-1}$ per $\mathrm{mg} \mathrm{L}^{-1}$ (Lewis 2011). For both lakes, the maximum concentrations occurred in September 2007 (El Sol $2.4 \mathrm{mg} \mathrm{L}^{-1}$, La Luna $1.4 \mathrm{mg} \mathrm{L}^{-1}$ ). Averaged across months, contributions to $\mathrm{K}_{\mathrm{t}}$ for TSS, water, chlorophyll, and DOC were, as \%, 62, 25, 8, 5 for El Sol, and 46, 47, 2,5 .

\section{Discussion}

Records for tropical lakes show that the vertical temperature range during stratification or over an annual cycle is $\sim 1.5{ }^{\circ} \mathrm{C}$ for equatorial latitudes and $5-6{ }^{\circ} \mathrm{C}$ for lakes near the margin of the tropics (Lewis 1983a, 1996; Layden et al. 2015). The thermal ranges of El Sol and La Luna $\left(\sim 11^{\circ} \mathrm{C}\right)$ apparently are magnified by elevation. A predicted surface temperature for El Sol and La Luna (4200 $\mathrm{m}$ elevation and $19^{\circ}$ latitude) based on mean normal lapse rate is $13{ }^{\circ} \mathrm{C}$ (Lewis 1983a); the observed maximum observed surface temperatures were somewhat lower (11-12 ${ }^{\circ} \mathrm{C}$, Fig. 2). More importantly, the maximum temperatures were sustained only briefly. Surface temperatures changed substantially from month to month, as indicated by the high annual temperature range of $\mathrm{El} \mathrm{Sol} \mathrm{and} \mathrm{La}$ Luna as compared with tropical lakes at lower latitude.

The close relationship of thermal surges with high solar irradiance indicates no overriding influence of wind on multiple episodes of heating and cooling in the lakes. Surface heat uptake for lakes reflects total irradiance, 
including infrared $(\sim 54 \%)$ and PAR $(\sim 46 \%)$ components (Talling 1982). For a stratified lake, irradiance below the mixed layer consists only of PAR, as infrared is absorbed near the surface. Therefore, deep warming by solar irradiance can be explained by factors that control PAR irradiance, i.e., DOC, TSS, and chlorophyll. In La Luna, which is more isolated than El Sol and had low DOC that likely was of natural origin. El Sol has more intensive exposure to humans and cattle (soil disturbance and organic waste) than La Luna, which likely explains its higher DOC concentrations. For neither lake would the watershed component of DOC have been strongly chromatic (i.e., it would not have had a high fraction of humic and fulvic acids) because the watersheds are barren, and therefore would have no strong effect on $\mathrm{K}_{\mathrm{T}}$. Also, high UV exposure of the water column in high mountain tropical lakes can degrade chromatic DOC more rapidly than would be expected in lakes at high latitude (Rose et al. 2009; Aguilera et al. 2013). TSS concentrations were very low in La Luna, but were moderately high in El Sol, thus affecting transparency. TSS transport probably reflects seasonal runoff. Cattle and human traffic would augment TSS transport by soil disturbance.

\section{Heat flux and stability}

The effects of high elevation on El Sol and La Luna can be demonstrated by comparison with heat budget data on Lake Valencia, Venezuela $\left(10^{\circ} \mathrm{N}, 420 \mathrm{~m}\right.$ amsl). For Valencia, 95th percentile heat gain over 2 years was near $50 \mathrm{cal} \mathrm{cm}^{-2}$ day $^{-1}$, as compared with more than three times that amount for El Sol and La Luna (Table 1). Heat loss (95th percentile) for Lake Valencia was near -100 , which is more than twice as much for El Sol and La Luna (Table 1). In Lake Valencia, seasonality of heat flux was dominant over daily variance in heat flux, whereas El Sol and La Luna showed strong dominance of short term variance in heat flux as compared with seasonal trends. The temperature range for $\mathrm{El} \mathrm{Sol}$ and La Luna was near $12{ }^{\circ} \mathrm{C}$ for the year, whereas Lake Valencia had range of $2.5^{\circ} \mathrm{C}$. As for all lakes, solar irradiance was the strongly dominant heat source, but maximum irradiance for El Sol and La Luna was 40\% higher than for Lake Valencia. As a result, humidity (including cloud cover), which was seasonally substantial for El Sol and La Luna, had proportionally a much greater effect on daily heat flux than was the case for Lake Valencia, as shown by the inverse relationship between humidity and solar irradiance for El Sol and La Luna (Fig. 2); humidity reduces the short wave radiation entering a lake (Fink et al. 2014).

Evaporative heat flux was very high in Lake Valencia and showed strong seasonal variation $\left(-250\right.$ to $-400 \mathrm{cal} \mathrm{cm}^{-2}$ day $^{-1}$ ) daily; sensible heat loss was insignificant by comparison (mean, $-26 \mathrm{cal} \mathrm{cm}^{-2} \mathrm{day}^{-1}$ ). These two flux components cannot be separated for El Sol and La Luna. Intraday sensible heat loss may have been higher, given the less dense air mass above lakes at such high elevation, but humidity would have had a suppressing effect on sensible heat loss. Therefore, most of the daily heat loss likely was evaporative. Suppression of heat gain by atmospheric moisture was the major cause of short-term and seasonal variance in net heat flux for El Sol and La Luna.

The annual heat budgets of El Sol and La Luna are nearly identical at $4000 \mathrm{cal} \mathrm{cm}^{-2}$. As compared with tropical lakes at lower elevation (e.g., the much larger Valencia at $5300 \mathrm{cal} \mathrm{cm}^{-1}$ ), these budgets appear to be magnified by the heat flux characteristics associated with high elevation. Three small lakes $\left(1-6 \mathrm{~km}^{-2}\right)$ in Ethiopia $\left(9^{\circ} \mathrm{N}\right)$ had annual budgets of $\sim 3000-6000 \mathrm{cal} \mathrm{cm}^{-2}$ (Wood et al. 1976), suggesting that substantial additional elevation for El Sol and La Luna did not greatly- affect annual heat budgets. Definitive quantification of the effects of size and depth, which are important regulators of heat budgets for temperate lakes (Gorham 1964), cannot yet be generalized for tropical lakes, but the maximum budgets appear to be clustered near $5000 \mathrm{cal} \mathrm{cm}^{-2}$ year $^{-1}$, whereas temperate lakes (Kalff 2002) show larger budgets and greater variation with area and depth.

\section{Rhythmic heat gain and loss}

Rhythmic episodes of heating and cooling apparently have not been reported in the literature for lakes. Rhythmicity of this type may be unusual, or may occur under some circumstances but without being detected because it would not be evident from weekly or biweekly temperature profiles in lakes. One direct comparison can be made with a recent study by Michuletti et al. (2016) who used continuously recording thermistors at multiple depths to show mixing patterns for four equatorial lakes between 3000 and $4000 \mathrm{~m}$ amsl in the Andes of Ecuador. The equatorial lakes showed no clear thermal seasonality because the hemispheric seasonality evident at higher or lower tropical latitudes is suppressed near the equator (Talling and LeMoalle 2000). The lakes showed multiple episodes of warming and cooling that were rhythmic and developed through heating and cooling events that defined the beginning and end of each stratification episode involving heat uptake or loss over a period of multiple days. These patterns are most evident from raw data provided as a supplement to the publication; color coded temperature maps do not show the sequences as clearly. The sequencing of the warming and cooling episodes did not show rhythmic spacing. The rhythmic discontinuous polymixis of El Sol is associated with weather conditions that may not occur near the equator.

For temperate lakes, stratification has high seasonal stability and therefore is weakly responsive to diel and 
intraseasonal warming and cooling. Variance in wind strength and in heat flux does affect temperate lakes through its effects on turbulence of the mixed layer, even when the mixed layer is dimensionally stable (MacIntyre and Melack 2009). Analysis of weather related changes in lakes has been uncommon, however, because continuous recording of water column temperatures, although feasible for at least two decades, has not often been used for analyzing short term temporal responses of lakes to weather over the entire water column.

Studies by Stauffer (1980) of wind power over Lake Mendota and a portion of Lake Ontario showed potential for periodicity of wind strength that could affect turbulence of the mixed layer of temperate lakes. Stauffer quantified a peak autocorrelation of 7 days during the warm season that reflected changes in wind strength and cloudiness causing suppression of solar irradiance; these events were followed by a return to lower wind strength and high solar irradiance. Effects on the lakes were not studied.

In contrast with temperate lakes, tropical lakes often show nonseasonal changes in thickness of the mixed layer in response to cooling episodes accompanied by wind (Lewis 1987, 1996). For Lake Valencia, Venezuela $\left(10^{\circ} \mathrm{N}, 410 \mathrm{~m}\right.$ amsl), autocorrelation in mixed layer thickness was negatively significant at 3 weeks, indicating periodic change in thickness.

Movement of isotherms by wind can occur through generation of internal waves. Antenucci et al. (2000) give strong empirical evidence of periodic isotherm displacement derived from a periodic (24-h) marine onshore wind for Lake Kinneret that resulted in a wave with $24-\mathrm{h}$ periodicity and weaker but documented Poincaré waves. Thorpe (1974) gives theoretical support for consistency in seiche amplitudes in Loch Ness that would account for periodicity in isotherm displacement over multiple days or weeks. Woolway and Simpson document a 24-h wind-driven periodicity affecting a seiche in Lake Windermere during early seasonal stratification. These studies reveal multiple mechanisms for periodicity caused by wind, but probably are not applicable to El Sol, which showed 30-day periodicities rather than the shorter (24-h) periodicities that correspond to daily change in wind velocities.

\section{Contrasts between El Sol and La Luna}

The contrasting responses of El Sol and La Luna to heating and cooling episodes require explanation. The two lakes differed only slightly in maximum and mean depth. La Luna is smaller and had almost twice the relative depth of El Sol, which would seem to favor greater stability for La Luna than for El Sol in response to net heat gain per unit area (Kalff 2002), but wind had no detectable effect on short term stratification patterns for the two lakes. Both lakes had very small fetch, which would have suppressed the influence of wind on turbulence of the mixed layer.

Differences in transparency explain the differences in stability of El Sol and La Luna. El Sol absorbed PAR irradiance over depth at twice the rate of La Luna. At times of high heat gain coinciding with warming, e.g., $\sim 120 \mathrm{cal} \mathrm{cm}^{-2}$ day $^{-1}$ of PAR irradiance, $65 \%$ of PAR was absorbed in the top $3 \mathrm{~m}$ of El Sol, which caused warming of $\sim 0.4{ }^{\circ} \mathrm{C}_{\text {day }}{ }^{-1}$, as reflected in upsurges of temperature over 5-day intervals. For La Luna, PAR generated irradiance absorbed in the $0-3 \mathrm{~m}$ layer during a warming surge was half as great $(36 \%$, $65 \mathrm{cal} \mathrm{cm}^{-2} \mathrm{day}^{-1}$ ), and the warming during heat surges was smaller than for El Sol. During a warming surge, El Sol warmed near the surface sufficiently to become stratified until a cooling phase began. La Luna did not reach a density gradient threshold that could offset nocturnal heat loss from the surface. As a result, El Sol was discontinuous warm polymictic, whereas La Luna was continuous warm polymictic. The cause for differing transparency of the lakes is suspended solids and chlorophyll, which differ for the two lakes, probably because of anthropogenic mobilization of inorganic solids and nutrients for El Sol.

\section{Deep heating during stratification for El Sol}

A third feature of warming and cooling episodes that requires explanation is gradual warming of water in El Sol below the mixed layer. For La Luna, which mixed daily, comparable deep water warming that occurred during episodic warming phases can be explained by nocturnal convection that led to a daily isothermal condition.

Warming below the mixed layer for El Sol must be explained by downwelling PAR irradiance, which can be estimated from $\mathrm{K}_{\mathrm{t}}$, or by turbulence, the effect of which can be estimated as residual of other sources of warmth. Figure 5 shows that $6 \mathrm{~m}$ was near the bottom of the mixed layer, as it showed density gradients erratically for short intervals, whereas $8 \mathrm{~m}$ and $12 \mathrm{~m}$ showed strong, continuous warming during stratification. At $9 \mathrm{~m}$, heat from PAR irradiance during stratification was equivalent to $0.13,0.14$, and $0.16{ }^{\circ} \mathrm{C}$ day $^{-1}$ in June, July, and August; observed changes were 0.06, 0.06, $0.05^{\circ} \mathrm{C} \mathrm{day}^{-1}$. At $12 \mathrm{~m}$, observed PAR warming was $0.05,0.05,0.08^{\circ} \mathrm{C}$ day $^{-1}$, and observed was $0.04,0.05$, 0.03 . The water column at $9 \mathrm{~m}$ shows evidence of vertical heat transfer $(\sim 60 \%)$, as supported by the eddy diffusion coefficient at $9 \mathrm{~m}$, whereas $12 \mathrm{~m}$ shows no significant heat transfer. Eddy diffusion could not be measured at $12 \mathrm{~m}$ because of the presence of sediment just below $12 \mathrm{~m}$.

Tarabay et al. (1991), referencing Juday (1940), speculated that the two lakes could be warmed at depth by heat uptake of mud. This source of warming, hypothetically propagated laterally from the sediment surface across El Sol at $9 \mathrm{~m}$, could at most be $0.0017{ }^{\circ} \mathrm{C}$ day $^{-1}$ at $9 \mathrm{~m}$, for example, 
and would be $50 \%$ higher for La Luna at the same depth, i.e., not significant for either lake. The spatial heat transfer processes at a specific depth would be much more complex than assumed for the calculations, but the simplified calculations give no motivation for more realistic calculations.

The conclusion is that warming of water below the mixed layer of El Sol during surface warming surges is caused both by solar irradiance and by turbulence that moves heat below the mixed layer, in declining amounts with depth, to greater depths. Below the mixed layer, water of El Sol reflects only the greater warmth in the mixed layer above, not the trend in surface warmth, until multiday cooling causes convergence of temperature for upper and lower layers, which marks the end of an episodic stratification interval. The mode of warming for La Luna also must include both absorption of irradiance and turbulence but turbulence at depth could be either convective or wind generated, given that the nocturnal isothermal condition would maximize the influence of wind, in contrast to the circumstances of El Sol.

Significant turbulence below the mixed layer in El Sol during periods of stratification seems anomalous in that turbulence of lakes typically is weak below the mixed layer during stratification in temperate lakes (Wüest and Lorke 2003) or even in tropical lakes at low elevation (Lewis 1982, 1983b), although nonseasonal cooling of a mixed layer may cause the thermocline to change position in lowland tropical lakes. For El Sol, the effectiveness of turbulence in moving substantial heat to points below the mixed layer during warming surges is consistent with density gradients, which are much weaker at low temperatures than at high temperatures. For example, the density gradient for a temperature transition of $1{ }^{\circ} \mathrm{C}$ below the mixed layer in El Sol would be $0.00009 \mathrm{~g} \mathrm{~cm}^{-3}$, but a comparable density gradient in a lowland tropical lake at a temperature of $25{ }^{\circ} \mathrm{C}$ would be three times higher $\left(0.00025 \mathrm{~g} \mathrm{~cm}^{-3}\right)$. Whereas water below the mixed layer in general has low turbulence at all locations except at the sediment-water boundary (Wüest and Lorke 2003), a lake at high elevation in the tropics, or at high latitude (MacIntyre and Melack 2009), may show propagation of significant turbulence downward from a mixed layer whose boundary is weak because of low density gradients at low temperatures.

Lakes El Sol (discontinuous warm polymictic) and $\mathrm{La}$ Luna (continuous warm polymictic) are qualitatively different in water column dynamics even though they are adjacent to each other and have nearly the same depth. The contrast between the two lakes is based on the strong influence of quantitatively minor watershed effects on PAR absorbance of irradiance per unit of depth in lakes of the high mountain tropical environment, where the influence of seasonality on water density is weak. Modest anthropogenic influences on transparency of these lakes have caused them to be quantitatively different with respect to stratification and mixing.
The sensitivity of El Sol and La Luna to mild pollution has ecological implications for high mountain lakes in general. As a class, these lakes can be expected to have high transparency, to be oligotrophic, and to have weak density gradients. This combination of physical and chemical conditions creates high vulnerability of the lakes to any anthropogenic influence on transparency, in that a slight change in transparency can have large effects on layering and mixing, which determine the habitat of phytoplankton, zooplankton, and possibly fishes. Prevention of ecological change in these lakes thus requires a degree of protection much stricter than would be characteristic for most other categories of lakes.

Acknowledgements This research was supported by the Fondo Sectorial de Investigación Ambiental (Sectorial Fund for Environmental Research) (SEMARNAT-CONACYT-2015-1-262970) through the project "Los lagos del Nevado de Toluca, México: Centinelas para la detección y análisis de la vulnerabilidad socio-ecosistémica ante los impactos del cambio ambiental global" and by Programa de Investigación en Cambio Climático (PINCC-2012-2014) through the project "Los lagos del Nevado de Toluca, México: centinelas para la detección y análisis del cambio ambiental global". León Felipe Álvarez Sánchez preparing the bathymetric maps and morphometric lake features. Data analysis was conducted by the Center for Limnology, Cooperative Institute for Research in Environmental Sciences, University of Colorado Boulder.

Open Access This article is licensed under a Creative Commons Attribution 4.0 International License, which permits use, sharing, adaptation, distribution and reproduction in any medium or format, as long as you give appropriate credit to the original author(s) and the source, provide a link to the Creative Commons licence, and indicate if changes were made. The images or other third party material in this article are included in the article's Creative Commons licence, unless indicated otherwise in a credit line to the material. If material is not included in the article's Creative Commons licence and your intended use is not permitted by statutory regulation or exceeds the permitted use, you will need to obtain permission directly from the copyright holder. To view a copy of this licence, visit http://creativecommons.org/licenses/by/4.0/.

\section{References}

Aguilera X, Lazzaro X, Coronel JS (2013) Tropical high-altitude Andean lakes located above the tree line attenuate UV-A radiation more strongly than typical temperature alpine lakes. Photochem Photobiol Sci 12:1649-1657

Alcocer DJ (1980) Aportaciones limnológicas al estudio del 'Lago del Sol' y 'Lago de la Luna', Nevado de Toluca, Edo. de México, Tesis de Licenciatura, UAM Iztapalapa

Antenucci JP, Imberger J, Saggio A (2000) Seasonal evolution of the basin-scale internal wave field in a large stratified lake. Limnol Oceanogr 45:1621-1638

Arce JL, Cervantes KE, Macías JL, Mora JC (2005) The $12.1 \mathrm{ka}$ Middle Toluca Pumice: a dacitic Plinian-subplinian eruption of Nevado de Toluca in Central Mexico. J Volcanol Geotherm Res 147:125-143

Eggermont H, Russel JM, Schettler G, Damme KV, Bessems I, Verschuren D (2007) Physical and chemical limnology of alpine lakes 
and pools in the Rwenzori Mountains (Uganda-DR Congo). Hydrobiologia 592:151-173

Fink G, Schmid M, Wahl B, Wolf T, Wüest A (2014) Heat flux modifications related to climate-inducing warming of large European lakes. Water Resour Res 50(3):2072-2085

Gorham E (1964) Morphometric control of annual heat budgets in temperate lakes. Ecol Evol Behav 9(4):525-529

Gunkel G, Casellas J (2002) Limnology of an equatorial high mountain lake-Lago San Pablo, Ecuador: the significance of deep diurnal mixing for lake productivity. Limnologica 32:33-43

Hutchison GE, Löffler H (1956) The thermal classification of lakes. Proc Natl Acad Sci 42:84-86

Idso SB (1973) On the concept of lake stability. Limnol Oceanogr 18:681-683

Jassby A, Powell T (1975) Vertical patterns of eddy diffusion during stratification in Castle Lake, California. Limnol Oceanogr 20:530-543

Juday C (1940) The annual energy budget of an inland lake. Ecology $21: 438-450$

Kalff J (2002) Limnology. Prentice Hall, New Jersey, p 592

Kirk JTO (1974) Light and photosynthesis in aquatic ecosystems, 2nd edn. Cambridge, New York

Layden A et al (2015) Global climatology of surface water temperatures of large lakes by remote sensing. Int J Climatol 35:4464-4479

Lewis WM Jr (1982) Vertical eddy diffusivities in a large tropical lake. Limnol Oceanogr 27:161-163

Lewis WM (1983a) A revised classification of lakes based on mixing. Can J Fish Aquat Sci 40:1779-1787

Lewis WM (1983b) Temperature, heat, and mixing in Lake Valencia, Venezuela. Limnol Oceanogr 28(2):273-286

Lewis WM Jr (1987) Tropical limnology. Annu Rev Ecol Syst 18:159-184

Lewis WM (1996) Tropical lakes: how latitude makes a difference. In: Schiemer F, Boland KT (eds) Perspectives in tropical limnology. SPB Academic Publishing, Amsterdam, pp 43-64

Lewis WM Jr (2011) Global primary production of lakes: 19th Baldi Memorial Lecture. Inland Waters 1:1-28

Löffler H (1964) The limnology of tropical high-mountain lakes. Verhandlungen Internationale Vereinigung für Theoretische und Angewandte Limnologie 15:176-193

Löffler H (1972) Contribution to the limnology of high mountain lakes in Central America. Int Rev Gesamten Hydrobiol 57(3):397-408

MacIntyre S, Melack JM (2009) Mixing dynamics in lakes across climatic zones. In: Likens GE (ed) Encyclopedia of inland waters, vol 1. Elsevier, Oxford, pp 603-612

Melack JM, MacIntyre S (2016) Morphometry and physical processes of East African Soda Lakes. In: Schagerl M (ed) Soda lakes of east Africa. Springer, Cham

Michuletti N, Labaj AL, Grooms C, Smol JP (2016) Equatorial mountain lakes show extended periods of thermal stratification with recent climate change. J Limnol 75(2):403-408
Read JS, Rose KC (2013) Physical responses of small temperate lakes to variation in dissolved organic carbon concentrations. Limnol Oceanogr 58:921-931

Reynolds C (2006) The ecology of phytoplankton (ecology, biodiversity and conservation). Cambridge University Press, Cambridge

Richerson PJ, Neale PJ, Wurtsbaugh W, Alfaro TR, Vincent W (1986) Patterns of temporal variation in Lake Titicaca, a high altitude tropical lake. Hydrobiologia 138:205-220

Rose KC, Williamson CE, Saros JE, Sommaruga R, Fischer JM (2009) Differences in UV transparency and thermal structure between alpine and subalpine lakes: implications for organisms. Photochem Photobiol Sci 8(9):1244-1256

Rose KC, Winslow LA, Read JS, Hansen GJA (2016) Climate-induced warming of lakes can be either amplified or suppressed by trends in water clarity. Limnol Oceanogr Lett 1:44-53

Salas De Leon DA, Alcocer J, Ardiles Gloria V, Quiroz-Martinez B (2016) Estimation of the eddy diffusivity coefficient in a warm monomictic tropical lake. J Limnol 75(1):161-168

Stauffer RE (1980) Windpower time series above a temperate lake. Limnol Oceanogr 25(3):513-528

Talling JF (1982) Utilization of solar radiation by phytoplankton. In: Helene C, Charlier M, Montenay-Garestier T, Laustriat G (eds) Trends in photobiology. Plenum, New York, pp 619-631

Talling JF, Lemoalle J (2000) Ecological dynamics of tropical inland waters. Cambridge University Press, Cambridge

Tarabay AB, Villela RG, Espino GL (1991) Limnological aspects of a high-mountain lake in Mexico. Hydrobiologia 224:1-10

Thorpe SA (1974) Near-resonant forcing in a shallow two-layer fluid: a model for the internal surge in Loch Ness? J Fluid Mech 63:509-527

Vincent WF, Neale PJ, Richerson PJ (1984) Photoinhibition on algal responses to bright light during diel stratification and mixing in a tropical alpine lake. J Phycol 20:201-211

Wood RB, Prosser MV, Baxter RM (1976) The seasonal pattern of thermal characteristics of four of the Bishoftu crater lakes, Ethiopia. Freshw Biol 6:519-530

Woolway RI, Merchant CJ (2019) Worldwide alteration of lake mixing regimes in response to climate change. Nat Geosci 12:271-276

Woolway RI, Simpson JH (2017) Energy input and dissipation in a temperate lake during the spring transition. Ocean Dyn 67(8):959-971

Wüest A, Lorke A (2003) Small-scale hydrodynamics in lakes. Annu Rev Fluid Mech 35:373-412

Publisher's Note Springer Nature remains neutral with regard to jurisdictional claims in published maps and institutional affiliations. 